\title{
Chemical Compounds, Pharmacological and Toxicological Activity of Brugmansia suaveolens: A Review
}

\author{
Vera L. Petricevich ${ }^{1}\left(\mathbb{D}\right.$, David Osvaldo Salinas-Sánchez ${ }^{2}$, Dante Avilés-Montes ${ }^{3}$, \\ Cesar Sotelo-Leyva ${ }^{4}$ and Rodolfo Abarca-Vargas ${ }^{1, *} *$
}

1 Faculty of Medicine, Autonomous University of the State of Morelos (UAEM), Street: Leñeros, esquina Iztaccíhuatl s/n. Col. Volcanes, Cuernavaca 62350, Morelos, Mexico; vera.petricevich@uaem.mx

2 Biodiversity and Conservation Research Center, Autonomous University of the State of Morelos (UAEM), Av. Universidad 1001, Col. Chamilpa, Cuernavaca 62209, Morelos, Mexico; davidos@uaem.mx

3 Faculty of Biological Science, Autonomous University of the State of Morelos (UAEM), Av. Universidad 1001, Col. Chamilpa, Cuernavaca 62209, Morelos, Mexico; dante.aviles@uaem.mx

4 Faculty of Chemistry-Biological Sciences, Autonomous University of Guerrero Av. Lázaro Cárdenas s/n, South University City, Chilpancingo 39000, Guerrero, Mexico; cesarsotelo@uagro.mx

* Correspondence: rodolfo.abarca@uaem.mx; Tel.: +52-777-361-2155

Received: 30 July 2020; Accepted: 3 September 2020; Published: 8 September 2020

\begin{abstract}
This study investigates updated information in different search engines on the distribution, phytochemistry, pharmacology, and toxicology of Brugmansia suaveolens (Solanaceae) using the extracts or chemical compounds at present. This plant has been used in traditional medicine in different cultures as a hallucinatory, analgesic, aphrodisiac, nematicide, sleep inducer, and muscle relaxant, as well as a treatment for rheumatism, asthma, and inflammation. The flowers, fruits, stems, and roots of the plant are used, and different chemical compounds have been identified, such as alkaloids, volatile compounds (mainly terpenes), coumarins, flavonoids, steroids, and hydrocarbons. The concentration of the different compounds varies according to the biotic and abiotic factors to which the plant is exposed. The toxic effect of the plant is mainly attributed to atropine and scopolamine, their averages in the flowers are $0.79 \pm 0.03$ and $0.72 \pm 0.05 \mathrm{mg} / \mathrm{g}$ of dry plant, respectively. Pharmacological studies have shown that an aqueous extract exhibits the antinociceptive effect, at doses of 100 and $300 \mathrm{mg} / \mathrm{kg}$ i.p. in mice. On the other hand, the ethanolic extract at $1000 \mathrm{mg} / \mathrm{L}$, showed a nematocidal activity in vitro of $64 \%$ against Meloidogyne incognita in $72 \mathrm{~h}$. Likewise, it showed a $100 \%$ larvicidal activity at $12.5 \mathrm{mg} / \mathrm{L}$ against Ancylostoma spp. In another study, the lethal activity of shrimp in brine from an ethanolic extract showed an $\mathrm{LC}_{50}$ of $106 \mu \mathrm{g} / \mathrm{mL}$ at double serial concentrations of $1000-0(\mu \mathrm{g} / \mathrm{mL})$. Although there are pharmacological and phytochemical studies in the plant, they are still scarce, which has potential for the examination of the biological activity of the more than one hundred compounds that have been reported, many of which have not been evaluated.
\end{abstract}

Keywords: alkaloids; terpenoid; scopolamine; antinociceptive; nematicide; toxicity

\section{Introduction}

Brugmansia suaveolens (Humb. and Bonpl. ex Willd.) Bercht. and J.Presl is widely distributed in the world both as a spontaneous species and as an ornamental plant [1], mainly in areas with climates ranging from tropical and subtropical to temperate [2]. It belongs to the Solanaceae family, and according to The Plant List, 12 are recognized in this genus, including hybrids and a subspecies (Brugmansia arborea, $B . \times$ candida, $B . \times$ cubensis, $B . \times$ dolichocarpa, $B . \times$ insignis, $B$. longifolia, $B$. pittieri, B. $\times$ rubella, B. sanguinea, B. sanguinea subsp. vulcanicola, B. suaveolens, and B. versicolor) [1]. The objective 
of this review is to present complete and updated information on the current research regarding the distribution, phytochemistry, pharmacology, and toxicology of B. suaveolens, in order to identify its therapeutic potential and open new research opportunities. The most salient data were searched using the keyword "Brugmansia suaveolens" in Google Scholar, ScienceDirect, Wiley, Taylor and Francis, and PubMed. The synonyms, according to The Plant List, of B. suaveolens (Humb. and Bonpl. ex Willd.) Bercht. and C. Presl, are Brugmansia albidoflava (Lem.) Verschaff. ex Bosse (unresolved), Datura albidoflava Lem. (synonym), Datura arborea Mart. (synonym), Datura gardneri Hook. (synonym), Datura suaveolens Humb. and Bonpl. ex Willd. (synonym), Datura suaveolens f. albidoflava (Lem.) Voss (synonym), Datura suaveolens var. macrocalyx Sendtn. (synonym), Pseudodatura suaveolens Zijp (unresolved), and Stramonium arboreum Moench (unresolved) [1].

Brugmansia suaveolens is known by various names in different areas of the world, such as in Mexico (Floripondio or florifundio) [3], (Toloache de castilla) [4], Argentina (Floripón) [5], Peru (Misha Colambo (Snake)) [6], (Floripondio) [7], (Toe, Toe de flor blanca) [8], Brazil (Trombeteira or Cartucheira) [9], (Trompeta de Ángel) [10], Sweden (Angel's Trumpet) [11], Sir Lanka (Attana) [12], and in Indonesia (Kecubung Bunga Kuning and Kecubung Bunga Putih) [13], (Cubung) [14], Pakistan (Shaitani ganti/Bel Boti) [15], and Butan (Gangmeto) [16]. In many other countries, B. suaveolens is better known by the name Angel's Trumpet.

\section{Botany}

\subsection{Taxonomical Classification}

Brugmansia suaveolens, was discovered by Alexander von Humbold and Aimé Bonpland (Humb. Bonpl. Ex Willd.). It was first formally described by Friederich von Berchtold and Jan Presl, and published in Hortus suburbanus Londinensis [1] (Table 1).

Table 1. Taxonomical classification of Brugmansia suaveolens.

\begin{tabular}{cc}
\hline Kingdom & Plantae \\
\hline Subkingdom & Tracheobionta \\
\hline Superdivision & Spermatophyta \\
\hline Division & Magnoliophyta \\
\hline Class & Magnoliopsida \\
\hline Order & Solanales \\
\hline Family & Solanaceae \\
\hline Subfamilia & Solanoideae \\
\hline Tribe & Datureae \\
\hline Genus & Brugmansia \\
\hline Species & B. suaveolens [1]
\end{tabular}

Brugmansia suaveolens belongs to the group of woody plants [17], considered shrubs or small trees (Figure 1), with a length ranging from 1 to $6 \mathrm{~m}$ high. The petiole is $2-5 \mathrm{~cm}$ long; the leaf lamina, with the widest end below the middle part known as an elliptical 15-30 cm long and 5-12 cm wide; the corolla is formed by a tube with lobes of $25-30 \mathrm{~cm}$ long; and the basal half is a narrow tubular shape and abruptly expands to form extended lobes $10-15 \mathrm{~cm}$ long. The color of the flower is white or reddish. The fruit is narrow at the end and wide in the middle part, and is $20 \mathrm{~cm}$ long with a $2.5 \mathrm{~cm}$ diameter. Flowering begins in January and from April to November. It bears fruit from May to June and in October [3]. 


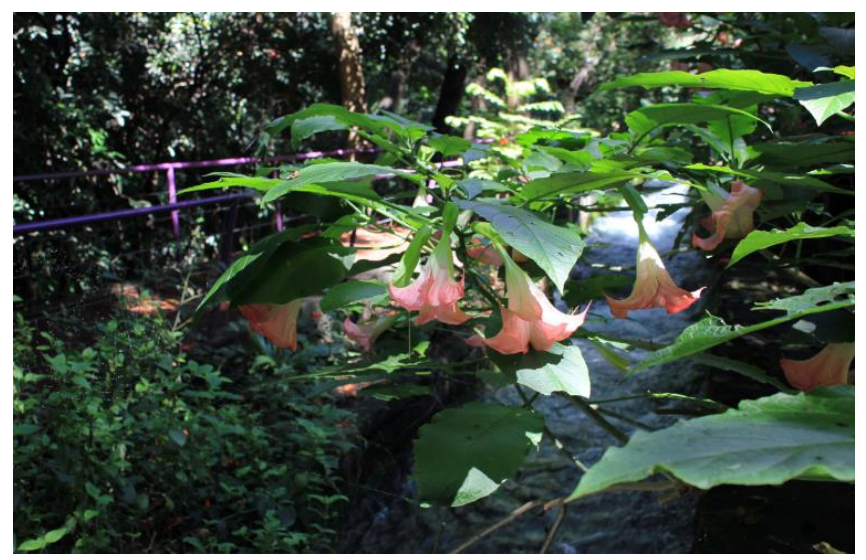

Figure 1. Brugmansia suaveolens.

\subsection{Distribution}

Brugamnsia suaveolens is widely distributed around the world (Figure 2), including in the USA [2], Mexico [18], Honduras, Nicaragua, Panama, El Salvador, Paraguay, and the Antilles [3], Argentina [19], Bolivia [20], Costa Rica [21], Colombia [22], Ecuador [23], Venezuela [24], Peru [6], Chile [25], Brazil [18], Korea [26], Vietnam [27], Taiwan [28], India [29], Indonesia [30], Butan [16], Sri Lanka [12], Pakistan [15], Turkey [31], Australia [32], New Zealand [33], Cameroon, Madagascar, Tanzania [3], Uganda [34], Italy, Bulgaria [35], Netherlands [35], Germany [36], Hungary [37], Greece [38], and Sweden [39].

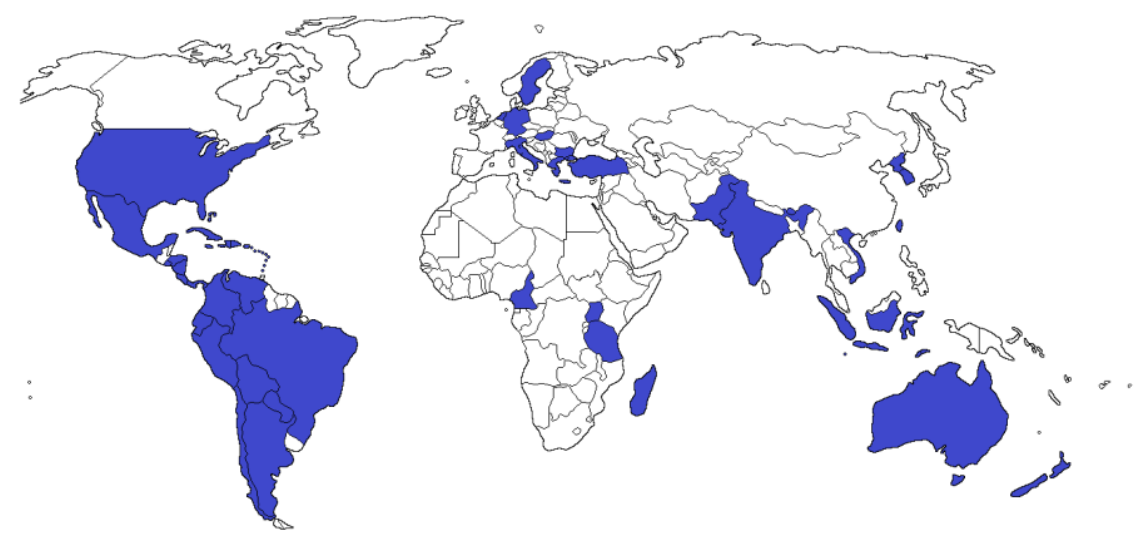

Figure 2. Global distribution map of Brugmansia suaveolens.

\subsection{Ethnobotany}

Many of these species are mainly appreciated as ornamentals, because of their ease of cultivation and the production of their characteristic flower smell at dusk [3], reaching its maximum peak at 21:00 [22]. B. suaveolens is also used in traditional medicine [3], despite being documented in the literature that its greatest use is as a hallucinogenic in shamanic rituals in some populations of Latin America [6], among them being some ethnic groups from the Amazon of Peru and Ecuador [40]. In the Inga people of Colombia, it is used externally to ward off the evil spirits that cause insomnia [41]. However, the first instances of its medicinal use were the Spanish in colonial times, where these plants were used for the treatment of rheumatism, infections, and asthma [42].

It is used to calm toothache [3]; to treat inflammation from trauma [6]; reduce general body inflammation [14]; for sores; to heal wounds without scars [6]; for treating pain in general [9], especially chest pain [43]; to treat abscesses, dermatitis, and fungal infections of the skin [44]; for snake bites; as an aphrodisiac [45]; for diarrhea [15]; gonorrhea; and for loss of appetite [14]. The flower buds are used to treat eye pain [46] and coughing [4]. 


\section{Phytochemistry}

Chemical studies of this medicinal species date back to 1996 [47]. Such studies were the first qualitative on groups of compounds, where they were identified as amines, carbohydrates [48], alkaloids, phenolic compounds, flavonoids, steroids, terpenoids, tannins, anthraquinone glycosides, saponins, and triterpenes. The quantification of the alkaloids $(5.903 \pm 0.01333 \mathrm{mg} / \mathrm{g})$, phenolic compounds $(3.435 \pm 0.0110 \mathrm{mg} / \mathrm{g})$, and flavonoids $(9.945 \pm 0.0256 \mathrm{mg} / \mathrm{g})$ was also carried out from the ethanolic extract of the flowers [49]. The concentrations of such compounds can vary, as in living flowers, they show a continuous change in the profile of their volatile compounds, which depend on intrinsic (genetic) and external factors (light, temperature, and water stress). In the case of the cut flowers, they suffer faster deterioration and a loss of volatile compounds [22]. Other factors that also affect it are attacks from pathogens (viruses, bacteria, fungi, and nematodes) and herbivores. The Marvin program was used to draw the structures of organic chemical compounds [50].

\subsection{Alkaloids}

Tropane alkaloids have anticancer activity [51]. Therefore, this group should be more studied in this regard. However, chemically, it is one of the most studied, where 59 alkaloids have been identified in the mature flowers, as well as in the immature flowers and fruits, corolla, flowers, roots, and flower nectar (Table 2 and Figure 3).

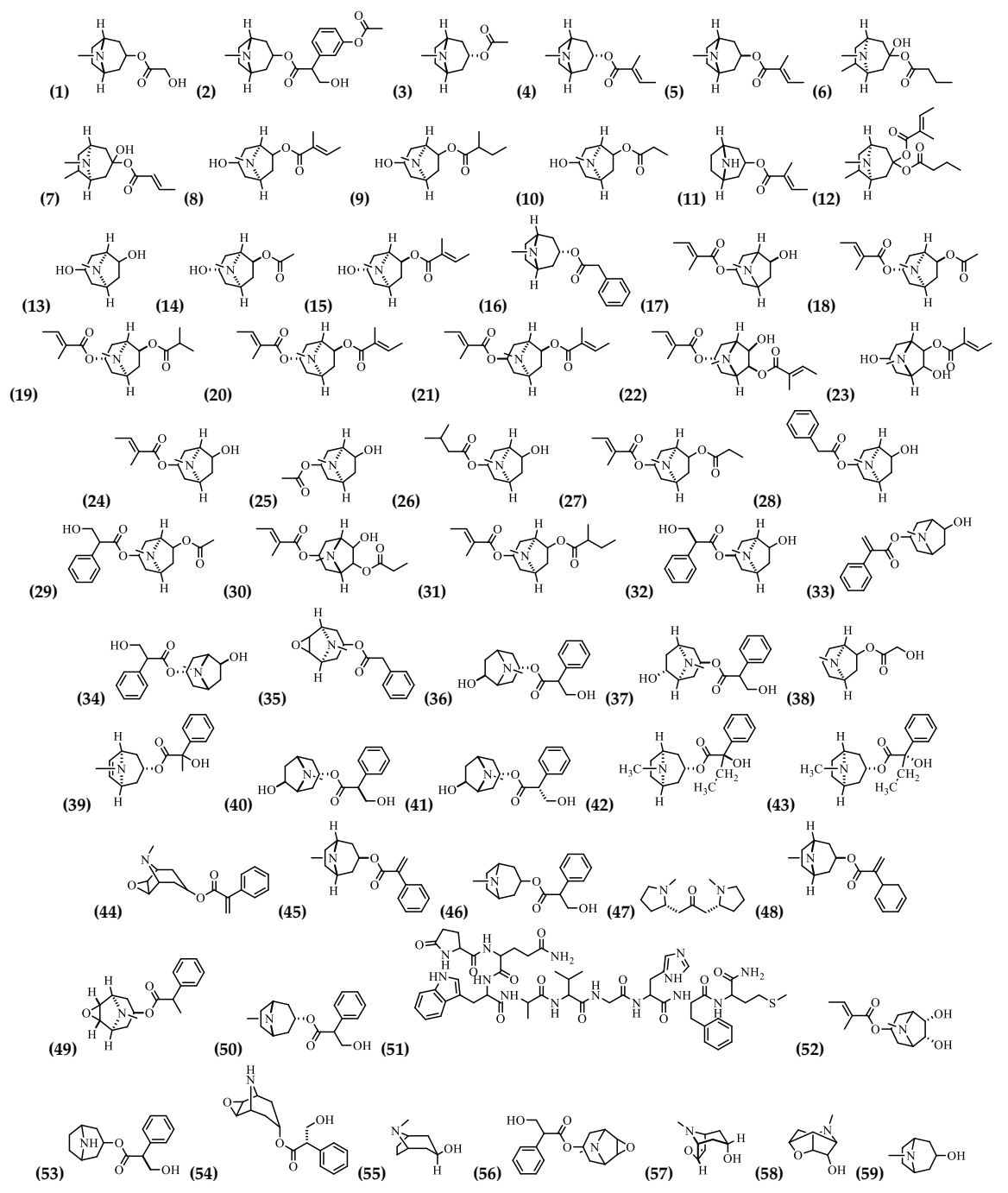

Figure 3. Structure of alkaloids from Brugmansia suaveolens. 
Table 2. Alkaloids from Brugmansia suaveolens.

\begin{tabular}{|c|c|c|}
\hline No. & Compound Name & Parts Used \\
\hline$(1)$ & 3-(Hydroxyacetoxy)-tropane & Roots [35] \\
\hline$(2)$ & 3-(3'Acetoxytropoyloxy)-tropane & Flowers, Roots [35] \\
\hline (3) & $3 \alpha$-Acetoxytropane & Root cultivation [36] \\
\hline$(4)$ & $3 \alpha$-Tigloyloxytropane & Flowers and Roots [35] \\
\hline$(5)$ & $3 \beta$-Tigloyloxytropane & Flowers [35] \\
\hline$(6)$ & 3-Hydroxy-6-methylbutyryloxy-tropane & Roots [35] \\
\hline$(7)$ & 3-Hydroxy-6-methyl-butenoyl-oxytropane & Flowers [47] \\
\hline$(8)$ & 3-Hydroxy-6-tigloyloxytropane & Root cultivation [36] \\
\hline$(9)$ & 3-Hydroxy-6-(2-methyl butyryloxy)-tropane & Root cultivation [36], Flowers, Roots [35] \\
\hline$(10)$ & 3-Hydroxy-6-propionyl-oxytropane & Flowers [47] \\
\hline (11) & 3-Tigloyloxynortropane & Flowers [35] \\
\hline$(12)$ & 3-Tigloyloxy-6-methylbutyryloxytropane & Flowers, Roots [35] \\
\hline (13) & 3,6-Dihydroxytropane & Flowers [47] \\
\hline$(14)$ & $3 \alpha$-Hydroxy- $6 \beta$-acetoxytropane & Flowers, Roots [35] \\
\hline (15) & $3 \alpha$-Hydroxy- $6 \beta$-tigloyloxytropane & Flowers, Roots [35] \\
\hline$(16)$ & $3 \alpha$-Phenylacetoxytropane & Roots [35] \\
\hline$(17)$ & $3 \alpha$-Tigloyloxy-6 $\beta$-hydroxytropane & Flowers, Roots [35] \\
\hline$(18)$ & $3 \alpha$-Tigloyloxy- $6 \beta$-acetoxytropane & Flowers [35] \\
\hline (19) & $3 \alpha$-Tigloyloxy- $6 \beta$-isobutyryloxytropane & Flowers, Roots [35] \\
\hline$(20)$ & $3 \alpha, 6 \beta$-Ditigloyloxytropane & Flowers, Roots [35] and Root cultivation [36] \\
\hline$(21)$ & $3 \beta, 6 \beta$-Ditigloyloxytropane & Roots [35] \\
\hline$(22)$ & $3 \alpha, 6 \beta$-Ditigloyloxy-7 $\beta$-hydroxytropane & Flowers [35] \\
\hline (23) & 3,6-dihydroxy-7-tigloyloxytropane & Flowers [35] \\
\hline$(24)$ & 3-Tigloyloxy-6-hydroxytropane & Root cultivation [36] \\
\hline$(25)$ & 3-Acetoxy-6-hydroxytropane & Root cultivation [36] \\
\hline$(26)$ & 3-Isovaleryloxy-6-hydroxytropane & Roots [35] \\
\hline (27) & 3-Tigloyloxy-6-propionyloxytropane & Flowers, and Roots [35] \\
\hline$(28)$ & 3-Phenylacetoxy-6-hydroxytropane & Flowers [35] \\
\hline$(29)$ & 3-Tropoyloxy-6-acetoxytropane & Flowers [35] \\
\hline$(30)$ & 3-Tigloyloxy-6-propionyloxy-7-hydroxytropane & Flowers, Roots [35] \\
\hline$(31)$ & 3-Tigloyloxy-6-(2-methylbutyryloxy)-tropane & Root cultivation [36] and Roots [35] \\
\hline$(32)$ & 7-Hydroxyhyoscyamine & Flowers [35] \\
\hline$(33)$ & 6-Hydroxyapoatropine & Flowers [47], Root cultivation [36], Roots [35] \\
\hline$(34)$ & 6-Hydroxyhyoscyamine & Flowers, Roots [35] \\
\hline$(35)$ & 3-Phenylacetoxy-6,7-epoxytropane & Flowers [52] \\
\hline$(36)$ & 6ß-Hydroxyhyoscyamine & Root cultivation [36] \\
\hline$(37)$ & $7 \beta$-Hydroxyhyoscyamine & Root cultivation [36] \\
\hline$(38)$ & 6-Hydroxyacetoxytropane & Flowers, Roots [35] \\
\hline$(39)$ & 6,7-Dehydronoratopine & Flowers [47] \\
\hline$(40)$ & 6R-Hydroxyhyoscyamine & Flowers [47] \\
\hline$(41)$ & 6S-Hydroxyhyoscyamine & Flowers [47] \\
\hline$(42)$ & 6R-Hydroxynorhyoscyamine & Flowers [47] \\
\hline$(43)$ & 6S-Hydroxynorhyoscyamine & Flowers [47] \\
\hline$(44)$ & Aposcopolamine & Flowers [47], Root cultivation [36], and Roots [35] \\
\hline$(45)$ & Apoatropine & Flowers [47], Root cultivation [36], and Roots [35] \\
\hline
\end{tabular}


Table 2. Cont.

\begin{tabular}{lcc}
\hline No. & Compound Name & Parts Used \\
\hline$(46)$ & Atropine & Root cultivation [36], and Corolla [53] \\
\hline$(47)$ & Cuscohygrine & Root cultivation [36] \\
\hline$(48)$ & Dihydroapoatropine & Flowers [47] \\
\hline$(49)$ & Dihydroaposcopolamine & Flowers [47] \\
\hline$(50)$ & Hyoscyamine & Flowers [35] \\
\hline$(51)$ & Litorine & Flowers [47] \\
\hline$(52)$ & Meteloidine & Flowers [47] \\
\hline$(53)$ & Norhyoscyamine & Root cultivation [36], Flowers, Roots [35] \\
\hline$(54)$ & Norscopolamine & Ripe flowers, and immature flowers and fruits [54], Corolla [53], \\
\hline$(55)$ & Pseudotropine & Flowers [47], Roots [35], and Flowers nectar [37] \\
\hline$(56)$ & Scopolamine & Root cultivation [36], Flowers [47] \\
\hline$(57)$ & Scopine & Root cultivation [36] \\
\hline$(58)$ & Scopoline & Flowers, and Roots [35] \\
\hline$(59)$ & Tropine &
\end{tabular}

\subsection{Volatile Compounds}

In the flowers and leaves, 50 volatile compounds have been identified and most of these compounds are found in the flowers (Table 3 and Figure 4).

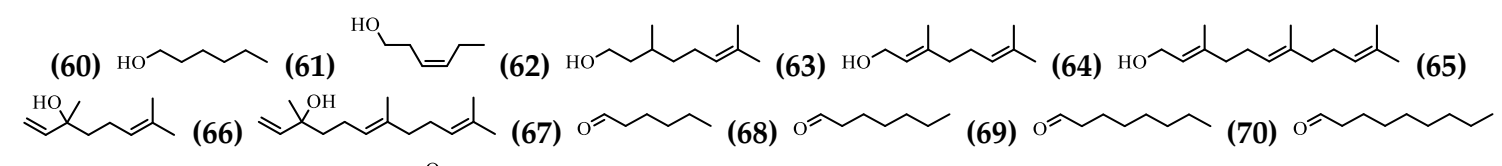

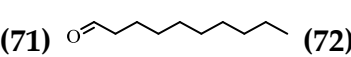<smiles>CC(C)=CCC(C)=CC=O</smiles>
(73)<smiles>CCCC=C(C)CC=C(C)C</smiles>

(74)<smiles>CCCCC(C)CCC(C)C</smiles>

至人<smiles>Cc1ccc(C(C)CC(C)c2ccc(C)cc2)cc1</smiles>
(91) (92)

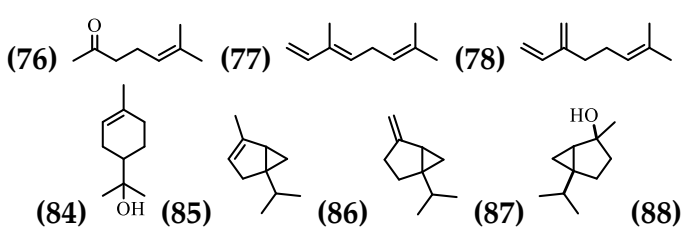
(79)<smiles>C/C=C(C)/C=C(\C)C(C)C</smiles>
(80)<smiles>CC=CC(C)=CC=C(C)C</smiles><smiles>C1CCCCC1</smiles>
(89)<smiles>c1ccc2ccccc2c1</smiles>
(90)<smiles>CC1CCC1</smiles><smiles>CCOC1CCCC1</smiles>
(93)

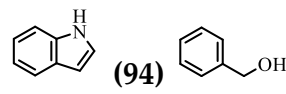<smiles>CCCc1ccccc1</smiles>
(96)<smiles>[C]1CC2C=CC1C2</smiles><smiles>C1CCCC1</smiles><smiles>C1=CC2CCCCC2C1</smiles>

(98)<smiles>COc1cccc(O)c1</smiles>

(99)<smiles>CC(C)CCc1ccccc1CC(=O)O</smiles>
(105)<smiles>CC(C)CCc1cccc2ccccc12</smiles>

(106)<smiles>C/C=C/C=C1C(C)=CC(=O)CC1(C)C</smiles>

(107)<smiles>C/C=C\C/C=C1\C(C)=CC(=O)CC1(C)C</smiles>

(108)<smiles>C/C=C/C=C1C(C)=CC(=O)CC1(C)C</smiles>

(109)<smiles>C/C=C\C=C1\C(C)C=C(O)CC1(C)C</smiles>

Figure 4. Structure of Volatile Compounds from Brugmansia suaveolens. 
Table 3. Volatile Compounds from Brugmansia suaveolens.

\begin{tabular}{|c|c|c|c|c|c|}
\hline No. & Compound Name & Parts Used & No. & Compound Name & Parts Used \\
\hline$(60)$ & Hexanol & Flowers [22] & $(85)$ & $\alpha$-Tujene & Flowers [22] \\
\hline (61) & (Z)-3-Hexen-1-ol & Flowers [22] & $(86)$ & Sabinene & Flowers [22] \\
\hline (63) & Geraniol & Flowers [22] & $(88)$ & 1,8-cineol & Flowers [22] \\
\hline (64) & (trans, trans)-Farnesol & Flowers [22] & $(89)$ & $\alpha$-Pinene & Flowers [22] \\
\hline (67) & Hexanal & Flowers [22] & (92) & 2-Isobutyl-3-methoxypyrazine & Flowers [21] \\
\hline (68) & Heptanal & Flowers [21] & (93) & Indole & Flowers [22] \\
\hline (69) & Octanal & Flowers [21] & (94) & Benzyl alcohol & Flowers [22] \\
\hline (70) & Nonanal & Flowers [22] & (95) & Phenethyl alcohol & Flowers [22] \\
\hline (74) & Citronellal & Flowers [22] & (99) & Methyl benzoate & Flowers [22] \\
\hline (75) & Farnesal & Flowers [22] & $(100)$ & Methyl salicylate & Flowers [22] \\
\hline (76) & 6-Methyl hept-5-en-2-one & Flowers [22] & $(101)$ & 3-phenyl lactic acid & Leaves [29] \\
\hline (77) & cis- $\beta$-Ocimene & Flowers [22] & $(102)$ & Benzyl benzoate & Flowers [22] \\
\hline (78) & $\beta$-Myrcene & Flowers [22] & $(103)$ & Benzyl salicylate & Flowers [22] \\
\hline (79) & Allo-ocimene & Flowers [22] & $(104)$ & 3-(3-indolyl) lactic acid & Leaves [29] \\
\hline$(80)$ & trans- $\beta$-Ocimene & Flowers [22] & $(105)$ & Indole-3-lactic acid methyl ester & Leaves [29] \\
\hline (81) & Terpinolene & Flowers [22] & $(106)$ & Megastigmatrienone I & Flowers [21] \\
\hline$(82)$ & $\gamma$-Terpinene & Flowers [21] & $(107)$ & Megastigmatrienone II & Flowers [21] \\
\hline (83) & Terpinen-4-ol & Flowers [22] & $(108)$ & Megastigmatrienone III & Flowers [21] \\
\hline
\end{tabular}




\subsection{Phenolic Compounds, Coumarin, and Flavonoids}

A glycosylated phenolic compound, a coumarin, and seven flavonoids have been identified, in the flowers and leaves (Table 4 and Figure 5).

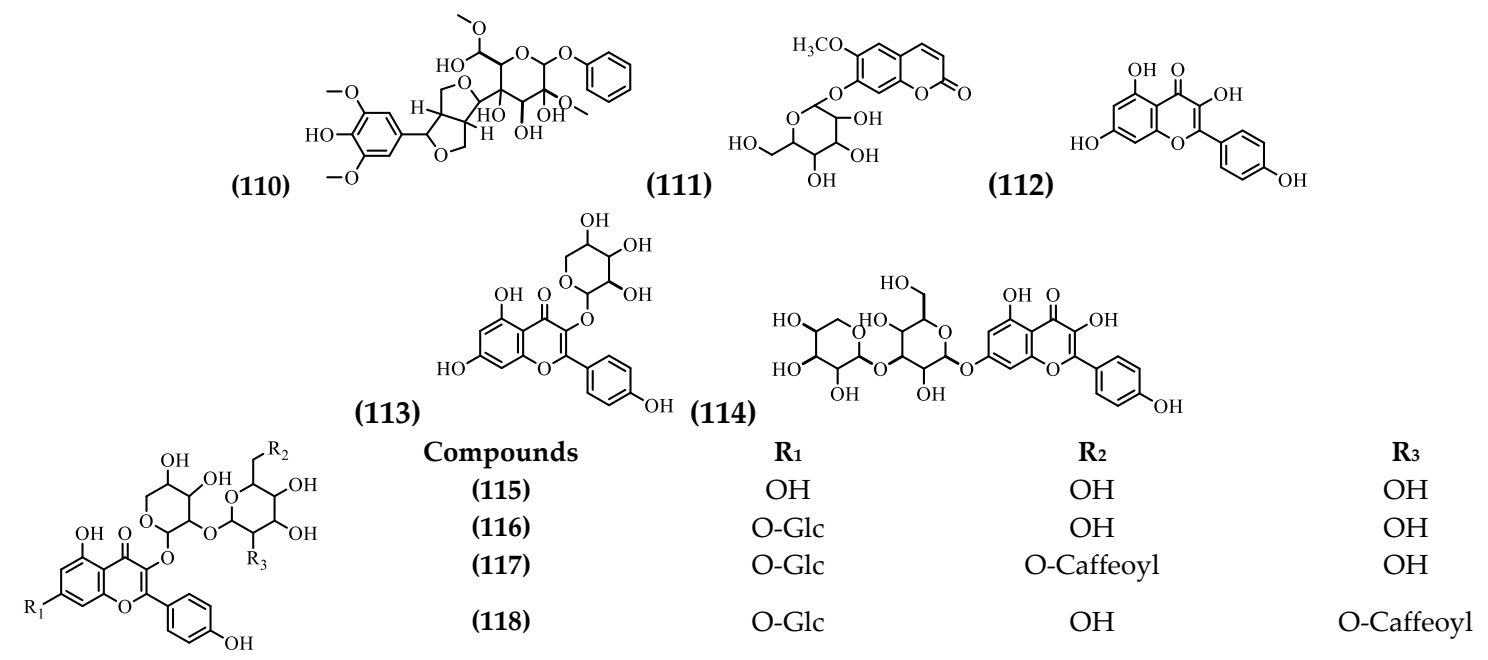

Figure 5. Structure of Phenolic Compounds, Coumarin, and Flavonoids from Brugmansia suaveolens.

\subsection{Steroids}

Three Steroids have been identified in the flowers and leaves (Table 5 and Figure 6).
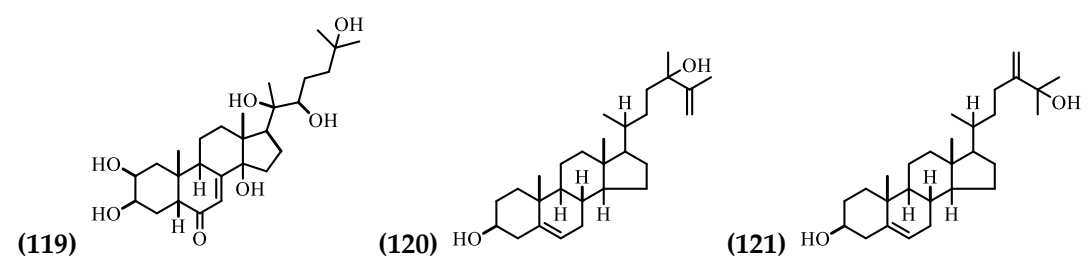

Figure 6. Structure of Steroids from Brugmansia suaveolens.

\subsection{Hydrocarbons}

The presence of four hydrocarbons in B. suaveolens has been identified only in the flowers (Table 6 and Figure 7).

(1)

(2)

(3)

(4)

Figure 7. Structure of the hydrocarbons from Brugmansia suaveolens. 
Table 4. Phenolic Compounds, Coumarin, and Flavonoids from Brugmansia suaveolens.

\begin{tabular}{|c|c|c|}
\hline No. & Compound Name & Parts Used \\
\hline (110) & Acanthoside B & Flowers [55] \\
\hline$(111)$ & Scopoletin 7-O- $\beta$-D-galactopyranoside & Flowers [55] \\
\hline$(112)$ & Kaempferol & Flowers [55] \\
\hline (113) & Kaempferol 3-O- $\alpha$-L-arabinopyranoside & Leaves [29] \\
\hline$(114)$ & kaempferol 3-O- $\alpha$-L-arabinopyranosyl-7-O- $\beta$-D-glucopyranoside & Leaves [29] \\
\hline (115) & 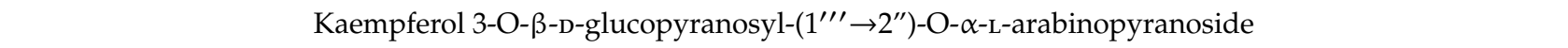 & Leaves [56] \\
\hline (116) & Kaempferol 3-O- $\beta$-D-glucopyranosyl-( $\left.1^{\prime \prime \prime} \rightarrow 2^{\prime \prime}\right)$-O- $\alpha$-L-arabinopyranoside-7-O- $\beta$-D-glucopyranoside & Leaves [56] \\
\hline$(117)$ & Kaempferol 3-O- $\beta$-D-[6"' -O-(E-caffeoyl)]-glucopyranosyl- $\left(1^{\prime \prime \prime} \rightarrow 2^{\prime \prime}\right)-\mathrm{O}-\alpha$-L-arabinopyranoside-7-O- $\beta$-D-glucopyranoside & Leaves [56] \\
\hline (118) & Kaempferol 3-O- $\beta$-D-[2"' -O-(E-caffeoyl)]-glucopyranosyl- $\left(1^{\prime \prime \prime} \rightarrow 2^{\prime \prime}\right)-\mathrm{O}-\alpha-\mathrm{L}-$ arabinopyranoside-7-O- $\beta$-D-glucopyranoside & Leaves [56] \\
\hline
\end{tabular}

Table 5. Steroids from Brugmansia suaveolens.

\begin{tabular}{clc}
\hline No. & Compound Name & Parts Used \\
\hline$(119)$ & 20-hydroxyecdysone & Flowers [55] \\
\hline$(120)$ & Physalindicanol A & Leaves [29] \\
\hline$(121)$ & Physalindicanol B & Leaves [29] \\
\hline
\end{tabular}

Table 6. Hydrocarbons from Brugmansia suaveolens.

\begin{tabular}{ccl}
\hline No. & Compound Name & Parts Used \\
\hline$(122)$ & Pentacosane & Flowers [21] \\
\hline$(123)$ & Heptacosane & Flowers [21] \\
\hline$(124)$ & Nonacosane & Flowers [21] \\
\hline$(125)$ & Hentriacontane & Flowers [21] \\
\hline
\end{tabular}




\section{Pharmacological Activity}

Brugmansia suaveolens is reported in traditional medicine in many Latin American countries; however, the first studies are from 22 years ago [4]. As there are very few pharmacological investigations of the plant, this is still an opportunity for future investigations.

\subsection{Antinociceptive}

The aqueous extract of B. suaveolens flowers was administered at doses of 100 and $300 \mathrm{mg} / \mathrm{kg}$ i.p. They significantly inhibited $(p<0.05)$ the induced contortions and increased the percentage of inhibition by acetic acid to $0.6 \%(3.0 \pm 0.8$ and $94.9 \%$, and $0.6 \pm 0.5$ and $99 \%$, respectively). Diclofenac $5 \mathrm{mg} / \mathrm{kg}$ i.p ( $43.4 \pm 3.5$ and $25.8 \%)$ was used as a positive control. An increase in the latency time was observed in the formalin test ( $20 \mu \mathrm{L}$ of $2.5 \%$ ); in the first phase (0-5 min), with a dose of $100 \mathrm{mg} / \mathrm{kg}$ $(15.6 \pm 4.2 \mathrm{~s}$ and $63.3 \%)$ and $300 \mathrm{mg} / \mathrm{kg}(0.3 \pm 0.3 \mathrm{~s}$ and $98.6 \%)$ and diclofenac $(43.6 \pm 7.0 \mathrm{~s}$ and $0 \%)$, and the second phase (20-25 $\mathrm{min})$ with a dose of $100 \mathrm{mg} / \mathrm{kg}(7.5 \pm 2.8 \mathrm{~s}$ and $82.2 \%)$ and $300 \mathrm{mg} / \mathrm{kg}$ $(0.0 \pm 0.0 \mathrm{~s}$ and $100 \%)$ and diclofenac $(7.0 \pm 2.8 \mathrm{~s}$ and $69.6 \%)$ in male Swiss albino mice. An increase in the latency time was also observed in the hot plate and tail dip tests [9].

In another study of the aqueous extract of flowers of B. suaveolens on the probable antinociceptive mechanism of the $300 \mathrm{mg} / \mathrm{kg}$ dose, a mechanism on benzodiazepine receptors was found. Flumazenil $(5 \mathrm{mg} / \mathrm{kg}$, i.p.) was used as an antagonist [57].

\subsection{Antimicrobial}

The antibacterial activity of the aqueous extract of B. suaveolens flowers against Bacillus thurigiensis was evaluated in one study and showed no activity [58].

\subsection{Nematicide}

The ethanolic extract of flowers at a concentration of $1000 \mathrm{mg} / \mathrm{L}$, showed a $64 \%$ in vitro nematocidal activity against Meloidogyne incognita within $72 \mathrm{~h}$. [49]. In another study of the ethanolic extract of aerial parts (flowers, and flowers and stems), a 100\% larvicidal activity at a dilution of $12.5 \mathrm{mg}$ against Ancylostoma spp was shown [59].

\subsection{Cytotoxicity}

Studies of the cytotoxic evaluation of the aqueous extract of B. suaveolens were carried out in the Brine-shrimp model (Artemia sp., Artemiidae) during $24 \mathrm{~h}$, the concentrations of 1000, 500, 250, 125, $62.5,31.25$, and $0(\mu \mathrm{g} / \mathrm{mL})$ were evaluated. An $\mathrm{LC}_{50}$ of $106 \mu \mathrm{g} / \mathrm{mL}$ was obtained [7].

\subsection{Muscle Relaxer}

Brugmansia suaveolens ethanol extract inhibits rabbit smooth muscle contractility at $100 \%$ at a concentration of $75.5 \mathrm{~g} / \mathrm{mL}$ [4].

\section{Toxicity}

There are several factors (climatic and seasonal) that can increase or decrease the concentration of the alkaloids associated with the toxicity of the plant. It has been documented that it has been involved in poisoning in many parts of the world, and other species, such as B. candida, B. sanguinea, and $B . \times$ candida, are considered toxic in some places like Mexico, especially their seeds. It is documented that an intake of 4 to $5 \mathrm{~g}$ of raw leaf, or just a seed, can cause a child to die [3]. Among the most toxic compounds are atropine and scopolamine, and their averages in the flowers are $0.79 \pm 0.03$ and $0.72 \pm 0.05 \mathrm{mg} / \mathrm{g}$ of dry plant, respectively; these concentrations will increase if the plant is fertilized with organic fertilizer $\left(6 \mathrm{~kg} / \mathrm{m}^{2}\right.$ per year) [44]. In another study, a scopolamine concentration of $149.80 \pm 6.01 \mu \mathrm{g} / \mathrm{mL}$ was determined in the flower nectar [37]. The plant parts that are the most involved in poisoning are flowers $(77.5 \%)$, leaves (13.4\%), fruits (4.5\%), stem (2.3\%), and root (2.3\%) [60]. 
The signs and symptoms of Angel's Trumpet poisoning are mydriasis, dry mouth, delirium, reddened skin [61], dry skin [60], agitation/aggressiveness, reduced bowel sounds [61], ileal paralysis, drowsiness [62], visual hallucinations, tachycardia, urinary retention, fever, increased systolic blood pressure, a Glasgow Coma Scale (GCS) of $<12$, [61], vertigo [60], decreased temperature and difficulty breathing prior to coma [3].

Unusual poisoning occurred in a five-year-old boy who consumed flowers, and as a consequence, unilateral tonic pupils and Guillain-Barré syndrome were observed [31].

\section{Conclusions}

This review details the distribution and ethnomedical, phytochemical, pharmacological, and toxicological uses of B. suaveolens in the world. The scientific investigations that have been carried out to date are scarce, the analgesic, cytotoxic, nematicidal, and antimicrobial activity has been studied. However, regarding it's chemistry, it is important to highlight that 125 compounds have been reported and identified, and a high percentage are not associated with pharmacological activity. Ethnomedical uses reported around the world include its uses to treat pain, insomnia, rheumatism, infections, asthma, inflammation, sores, wounds, abscesses, dermatitis, snakebites, loss of appetite, coughs, and as an aphrodisiac. From this empirical and traditional knowledge in different countries, the scientific validation of this plant species emerges as a great area of opportunity, which provides an opportunity for interdisciplinary collaboration between different research groups.

Author Contributions: Writing-original draft preparation, V.L.P., D.O.S.-S., D.A.-M., C.S.-L., and R.A.-V.; writing-review and editing, V.L.P., D.O.S.-S., D.A.-M., C.S.-L., and R.A.-V.; supervision, V.L.P., D.O.S.-S., D.A.-M., C.S.-L., and R.A.-V. All authors have read and agreed to the published version of the manuscript.

Funding: This research was funded by Secretaría de Educación Pública (SEP-PROMEP) and Consejo Nacional de Ciencia y Tecnología (CONACyT), Mexico under number ON.551-6/18-7513.

Acknowledgments: This work was supported by Secretaría de Educación Publica (SEP-PROMEP), Mexico. Photograph by M. en C. Gabriel Flores Franco, curator of the CIByC herbarium of the Autonomous University of the State of Morelos (UAEM).

Conflicts of Interest: The authors declare that they have no conflicts of interest. The funding sponsors contributed the scholarship payment, and had no role in the study design, collection, analysis, or interpretation of the data; in the writing of the manuscript; or in the decision to publish the results.

\section{References}

1. The Plants List. "Brugmansia suaveolens". 2020. Available online: http://www.theplantlist.org./tpl1.1/record/ kew-26840192020 (accessed on 18 August 2020).

2. Chellemi, D.O.; Webster, C.G.; Baker, C.A.; Annamalai, M.; Achor, D.; Adkins, S. Widespread occurrence and low genetic diversity of Colombian datura virus in Brugmansia suggest an anthropogenic role in virus selection and spread. Plant Dis. 2011, 95, 755-761. [CrossRef]

3. Monroy-Ortiz, C.; Monroy, R. Las Plantas, Compañeras de Siempre: La Experiencia en Morelos, 1st ed.; UAEM, Centro de Investigaciones Biológicas de la Conabio Conanp: Cuernavaca, Morelos, Mexico, 2006.

4. Encarnación-Dimayuga, R.; Altamirano, L.; Maki, K.A. Screening of medicinal plants from Baja California Sur (Mexico) by their effects on smooth muscle contractility. Pharm. Biol. 1998, 36, 124-130. [CrossRef]

5. Furlan, V.; Kujawska, M.; Hilgert, N.I.; Pochettino, M.L. To what extent are medicinal plants shared between country home gardens and urban ones? A case study from Misiones, Argentina. Pharm. Biol. 2016, 54, 1628-1640. [CrossRef] [PubMed]

6. De Feo, V. The ritual use of Brugmansia species in traditional Andean medicine in northern Peru. Econ. Bot. 2004, 58, S221-S229. [CrossRef]

7. Bussmann, R.W.; Malca, G.; Glenn, A.; Sharon, D.; Nilsen, B.; Parris, B.; Dubose, D.; Ruiz, D.; Saleda, J.; Martinez, M.; et al. A townesmith toxicity of medicinal plants used in traditional medicine in Northern Peru. J. Ethnopharmacol. 2011, 137, 121-140. [CrossRef]

8. Sanz-Biset, J.; Cañigueral, S. Plants as medicinal stressors, the case of depurative practices in Chazuta valley (Peruvian Amazonia). J. Ethnopharmacol. 2013, 145, 67-76. [CrossRef] 
9. Parker, A.; Goulart Peraza, G.; Sena, J.; Sinnott Silva, E.; Flores Soares, M.C.; Cezar Vaz, M.R.; Badiale Furlong, L.; Muccillo-Baisch, A.L. Antinociceptive effects of the aqueous extract of Brugmansia suaveolens flowers in mice. Biol. Res. Nurs. 2007, 8, 234-239. [CrossRef]

10. Lucinda, N.; Inoue-Nagata, A.K.; Kitajima, E.W.; Nagata, T. Complete genome sequence of Brugmansia suaveolens mottle virus, a potyvirus from an ornamental shrub. Arch. Virol. 2010, 155, 1729-1732. [CrossRef]

11. Hudák, J.; Walles, B.; Vennigerholz, F. The transmitting tissue in Brugmansia suaveolens L.: Ultrastructure of the stylar transmitting tissue. Ann. Bot. 1993, 71, 177-186. [CrossRef]

12. Jayawickreme, K.P.; Janaka, K.V.C.; Subasinghe, S. Unknowing ingestion of Brugmansia suaveolens leaves presenting with signs of anticholinergic toxicity: A case report. J. Med. Case Rep. 2019, 13, 1-4. [CrossRef]

13. Oktavia, A.I.; Indriani, S.; Jati, B. Ethnobotanical study of toxic plants in Ngadiwono Village, Tosari District, Pasuruan Regency, East Java. Indones. J. Environ. Sustain. Dev. 2017, 8, 83-88. [CrossRef]

14. Batoro, J.; Siswanto, D. Ethnomedicinal survey of plants used by local society in Poncokusumo district, Malang, East Java Province, Indonesia. Asian J. Med. Biol. Res. 2017, 3, 158-167. [CrossRef]

15. IjazaI, F.; IqbalbI, Z.; Ur RahmancI, I.; AlamdI, J.; Mulk KhaneI, S.; Mujtaba ShahfI, G.; KhangI, K.; AfzalhI, A. Investigation of traditional medicinal floral knowledge of Sarban Hills, Abbottabad, KP, Pakistan. J. Ethnopharmacol. 2016, 179, 208-233. [CrossRef] [PubMed]

16. Chetri, B.K.; Wangdi, P.; Penjor, T. Ethnomedicinal practices in Kilikhar, Mongar. Asian Plant Res. J. 2018, 1, 1-13. [CrossRef]

17. Bye, R.; Sosa, V. Molecular phylogeny of the jimsonweed genus Datura (Solanaceae). Syst. Bot. 2013, 38, 818-829. [CrossRef]

18. Safford, W.E. Synopsis of the genus Datura. J. Washingt. Acad. Sci. 1921, 11, 173-189. Available online: http://www.jstor.org/stable/24532461 (accessed on 25 March 2020).

19. Kujawska, M. Forms of medical pluralism among the Polish Community in Misiones, Argentina. Anthropol. Med. 2016, 23, 205-219. [CrossRef]

20. Hosking, J.R.; Conn, B.J.; Lepschi, B.J.; Barker, C.H. Plant species first recognised as naturalised or naturalising for New South Wales in 2004 and 2005. Cunninghamia 2011, 12, 85-114.

21. Anthony, S.J.; Zuchowski, W.; Setzer, W.N. Composition of the floral essential oil of Brugmansia suaveolens. Rec. Nat. Prod. 2009, 3, 76.

22. Stashenko, E.E.; Martínez, J.R. Sampling flower scent for chromatographic analysis. J. Sep. Sci. 2008, 31, 2022-2031. [CrossRef]

23. Mosquera-Yuqui, F.; Garrido, P.; Flores, F.J. Molecular characterization and complete genome of alstroemeria mosaic virus (AlMV). Virus Genes 2020, 56, 87-93. [CrossRef] [PubMed]

24. Giraldo, C.E.; Barbosa, E.P.; Freitas, A.V.L. Immature stages of Pagyris cymothoe cymothoe (Hewitson, 1855) (Lepidoptera, Danainae, Ithomiini). Trop. Zool. 2013, 26, 145-153. [CrossRef]

25. Danton, P.; Perrier, C.; de Reyes, G.M. Nouveau catalogue de la flore vasculaire de l'archipel Juan Fernández (Chili) Nuevo catálogo de la flora vascular del Archipiélago Juan Fernández (Chile). Acta Bot. Gall. 2006, 153, 399-587. [CrossRef]

26. Zhao, F.; Lim, S.; Yoo, R.H.; Lim, H.S.; Kwon, S.Y.; Lee, S.H.; Moon, J.S. Complete genome sequence of a South Korean isolate of Brugmansia mosaic virus. Arch. Virol. 2013, 58, 2019-2022. [CrossRef]

27. Mai, N.T. Quantitative analysis of scopolamine in Brugmansia suaveolens by HPLC-MS method. J. Multidiscip. Eng. Sci. Technol. 2017, 4, 8176-8179.

28. Lin, T.J.; Nelson, L.S.; Tsai, J.L.; Hung, D.Z.; Hu, S.C.; Chan, H.M.; Deng, J.F. Common toxidromes of plant poisonings in Taiwan. Clin. Toxicol. 2009, 47, 161-168. [CrossRef]

29. Sajeli Begum, A.; Sahai, M.; Fujimoto, Y.; Asai, K.; Schneider, K.; Nicholson, G.; Suessmuth, R. A new kaempferol diglycoside from Datura suaveolens Humb. \& Bonpl. ex. Willd. Nat. Prod. Res. 2006, 20, 1231-1236.

30. Suganda, A.G.; Nishiyama, Y.; Yamakawa, T.; Sugiyama, N. Random amplified polymorphic DNA analysis to distinguish Brugmansia suaveolens, B. candida and B. versicolor. Plant Biotechnol. 2006, 23, 519-520. [CrossRef]

31. Sevketoglu, E.; Tatlı, B.; Tuğcu, B.; Demirelli, Y.; Hatipoglu, S. An unusual cause of fulminant Guillain-Barré syndrome: Angel's trumpet. Pediatr. Neurol. 2010, 43, 368-370. [CrossRef]

32. Haegi, L. Taxonomic account of Datura L.(Solanaceae) in Australia with a note on Brugmansia Pers. Aust. J. Bot. 1976, 24, 415-435. [CrossRef]

33. Sykes, W.R. Checklist of dicotyledons naturalised in New Zealand 10. Polemoniales and Boraginaceae. N. Z. J. Bot. 1981, 19, 311-317. [CrossRef] 
34. Otim, A.S.; Kajobe, R.; Abila, P.P.; Kasangaki, P.; Echodu, R. Important plants for honey production in four agro ecological zones of Uganda. Bee World 2019, 96, 81-86. [CrossRef]

35. Doncheva, T.; Berkov, S.; Philipov, S. Comparative study of the alkaloids in tribe Datureae and their chemosystematic significance. Biochem. Syst. Ecol. 2006, 34, 478-488. [CrossRef]

36. Zayed, R.; and Wink, M. Induction of tropane alkaloid formation in transformed root cultures of Brugmansia suaveolens (Solanaceae). Z. Nat. C 2004, 59, 863-867. [CrossRef] [PubMed]

37. Kerchner, A.; Darók, J.; Bacskay, I.; Felinger, A.; Jakab, G. Protein and alkaloid patterns of the floral nectar in some solanaceous species. Acta Biol. Hung. 2015, 66, 304-315. [CrossRef] [PubMed]

38. Malandraki, I.; Papachristopoulou, M.; Vassilakos, N. First report of potato spindle tuber viroid (PSTVd) in ornamental plants in Greece. New Dis. Rep. 2010, 21, 9. [CrossRef]

39. Vennigerholz, F. The transmitting tissue in Brugmansia suaveolens: Immunocytochemical localization of pectin in the style. Protoplasma 1992, 171, 117-122. [CrossRef]

40. Bennett, B.C. Hallucinogenic plants of the Shuar and related indigenous groups in Amazonian Ecuador and Peru. Brittonia 1992, 44, 483-493. [CrossRef]

41. Laferriere, J.E. Medicinal plants of the Lowland Inga people of Colombia. Int. J. Pharmacogn. 1994, 32, 90-94. [CrossRef]

42. Schultes, E.R.; Plowman, T. The ethnobotany of Brugmansia. J. Ethnopharmacol. 1979, 1, 147-164. [CrossRef]

43. Lalzarzovi, S.T.; Lalramnghinglova, H. Traditional use of medicinal plants found within Aizawl city in Mizoram, India. Pleione 2016, 10, 269-277.

44. Reis, R.B.; Bragagnolo, F.S.; Gianeti, T.M.R.; Rodrigues, S.A.; Funari, C.S.; Gonçalves, G.G.; Ming, L.C. Brugmansia suaveolens leaf productivity and alkaloid contents under different doses of organic fertilizer. J. Agric. Sci. 2019, 11, 341-349. [CrossRef]

45. Carlini, E.A.; Maia, L.O. Plant and fungal hallucinogens as toxic and therapeutic agents. Toxinology 2015, 1, 1-44.

46. Rohman, F.; Juma, D.H.; Utomo, S.R.; Arifah, S.N.; Putra, W.E. Plants diversity as a medicinal plants by the Tengger Tribe, Bromo Tengger Semeru National Park, East Java, Indonesia. EurAsian J. Biosci. 2019, 13, 2293-2298.

47. Freitas, A.V.L.; Trigo, J.R.; Brown, K.S.; Witte, L.; Hartmann, T.; Barata, L.E.S. Tropane and pyrrolizidine alkaloids in the ithomiines Placidula euryanassa and Miraleria cymothoe (Lepidoptera: Nymphalidae). Chemoecology 1996, 7, 61-67. [CrossRef]

48. Sakunthala, P.; Charles, A.; Kesavan, D.; Ramani, V.A. Phytochemical screening and adsorption studies of Brugmansia suaveolens. Chem. Sci. Rev. Lett. 2013, 29, 319-322.

49. Nandakumar, A.; Vaganan, M.M.; Sundararaju, P.; Udayakumar, R. Phytochemical analysis and nematicidal activity of ethanolic leaf extracts of Datura metel, Datura innoxia and Brugmansia suaveolens against Meloidogyne incognita. Asian J. Biol. 2017, 2, 1-11. [CrossRef]

50. Marvin, “MarvinSketch 18.04". 2018. Available online: http://www.chemaxon.com (accessed on 25 March 2020).

51. Alam, E.A. In vitro cultures for the production of some anticancer agents. Life Sci. J. 2013, 10, $297-310$.

52. Pinto, C.F.; Salinas, S.; Flores-Prado, L.; Echeverría, J.; Niemeyer, H.M. Sequestration of tropane alkaloids from Brugmansia suaveolens (Solanaceae) by the treehopper Alchisme grossa (Hemiptera: Membracidae). Biochem. Syst. Ecol. 2016, 66, 161-165. [CrossRef]

53. Andreola, B.; Piovan, A.; Da Dalt, L.; Filippini, R.; Cappelletti, E. Unilateral mydriasis due to Angel's Trumpet. Clin. Toxicol. 2008, 46, 329-331. [CrossRef]

54. Alves, M.N.; Sartoratto, A.; Trigo, J.R. Scopolamine in Brugmansia suaveolens (Solanaceae): Defense, allocation, costs, and induced response. J. Chem. Ecol. 2007, 33, 297-309. [CrossRef] [PubMed]

55. Mai, N.T. Investigation on chemical constituents of the Brugmansia suaveolens flowers. J. Multidiscip. Eng. Sci. Technol. 2019, 6, 10021-10024.

56. Geller, F.; Murillo, R.; Steinhauser, L.; Heinzmann, B.; Albert, K.; Merfort, I.; Laufer, S. Four new flavonol glycosides from the leaves of Brugmansia suaveolens. Molecules 2014, 19, 6727-6736. [CrossRef] [PubMed]

57. Muccillo-Baisch, A.L.; Parker, A.G.; Cardoso, G.P.; Cezar-Vaz, M.R.; Flores Soares, M.C. Evaluation of the analgesic effect of aqueous extract of Brugmansia suaveolens flower in mice: Possible mechanism involved. Biol. Res. Nurs. 2010, 11, 345-350. [CrossRef] 
58. Vilani, A.; Lozano, E.R.; Potrich, M.; de Gouvea, A.; Martins Costa Maia, F.; Angeli Alves, L.F.; Dall Agnol de Lima, J. Activity of plant aqueous extracts on Bacillus thuringiensis and their interactions on Anticarsia gemmatalis (Lepidoptera: Erebinae). Semin. Ciências Agrárias 2017, 38, 1051-1057. [CrossRef]

59. Santos, I.D.; Souza, F.; Akisue, G.; da Coelho, S.F.A.; Coelho, M.D.G. Evaluation of ovicidal and larvicidal activity of ten plant extracts against Ancylostoma spp. Rev. Patol. Trop. 2013, 42, 209-216.

60. Doan, U.V.M.; Wu, L.; Phua, D.H.; Mendez Rojas, B.; Yang, C.C. Datura and Brugmansia plants related antimuscarinic toxicity: An analysis of poisoning cases reported to the Taiwan poison control center. Clin. Toxicol. 2019, 57, 246-253. [CrossRef]

61. Isbister, G.K.; Oakley, P.A.; Dawson, H.; Whyte, I.M. Presumed Angel's trumpet (Brugmansia) poisoning: Clinical effects and epidemiology. Emerg. Med. 2003, 15, 376-382. [CrossRef]

62. Fuchs, J.; Rauber-Lüthy, C.; Kupferschmidt, H.; Kupper, J.; Kullak-Ublick, G.A.; Ceschi, A. Acute plant poisoning: Analysis of clinical features and circumstances of exposure. Clin. Toxicol. 2011, 49, 671-680. [CrossRef]

(C) 2020 by the authors. Licensee MDPI, Basel, Switzerland. This article is an open access article distributed under the terms and conditions of the Creative Commons Attribution (CC BY) license (http://creativecommons.org/licenses/by/4.0/). 